of Russia scientific and educational centers for post-university training of managers and specialists from the sphere of business, state and municipal management, and organization of educational work among the population.

Keywords: strategy, new normality, sustainable development, human capital, green, digital economy, training, educational work

АЛИГАДЖИЕВА Мадина Алиевна - соискатель Российской академии народного хозяйства и государственной службы при Президенте РФ (119571, Россия, г. Москва, пр-кт Вернадского, 82, стр. 1; aligad_m@mail.ru)

\title{
КЛАНОВОЕ И ЭТНИЧЕСКОЕ РАЗМЫВАНИЕ ПОЛИТИЧЕСКОЙ ЭЛИТЫ ДАГЕСТАНА
}

Аннотация. Учитывая внутренние и внешние проблемы, с которыми столкнулась современная Россия, безусловно, возрастает и роль национально ориентированной элиты, главными трендами для которой должны стать созидание, сохранение и стабильность страны. Цель статьи - выявить клановое размывание политической элиты Республики Дагестан. Работа подготовлена на материалах социологических исследований, проведенных автором методом анкетирования. Полученные результаты целесообразно применять в рамках государственной политики РФ в сфере национальной политики и межконфессиональных отношений для более полной информированности органов государственной и муниципальной власти, общественных организаций и движений.

Ключевые слова: политическая элита, кланы, размывание, исследования, Дагестан

$\mathrm{K}$ лановая структура правления, присутствующая во многих регионах страны, лишает национальную элиту возможности созидательной и стабильной деятельности в интересах государства и для его пользы. Многочисленные попытки искоренить ее в Дагестане не увенчались успехом: она всегда возрождалась вновь. Большие надежды в этой области возлагались на Р.Г. Абдулатипова, от которого, учитывая отсутствие у него приверженности к каким-либо кланам, ожидали размывания этнической клановости в республике.

Исследования, которые проводились в 2013 г., показали, что, без сомнения, клановый принцип превалирует над всеми остальными критериями вхождения в политическую элиту. Так, на вопрос исследования, проведенного в февралемарте 2013 г. в Республике Дагестан: «Какие основные принципы вхождения в политическую элиту характерны для Республики Дагестан?» - наибольшее число респондентов отметили клановый принцип (76,9\%), 19,2\% отметили семейные и родственные отношения, и только 15,5\% выбрали вариант ответа «путем собственных усилий» [Алигаджиева 2014]. Причем надо отметить, что на Северном Кавказе процессы клановости в формировании политических элит гораздо сильнее выражены, чем на Южном ${ }^{1}$.

Аналогичное исследование было проведено в 2015 г. На вопрос: «Кому, на ваш взгляд, реально принадлежит нынешняя власть в республике?» - были получены следующие ответы: первому руководителю республики - 18,60\%, различным кланам - 15,80\%, коррумпированной части аппарата $-14,10 \%$, материально обеспеченным людям, предпринимателям, коммерсантам $-7,90 \%$,

1 Бодио Т. Политическое лидерство и политические элиты Кавказа. Доступ: https://bredikhinav. livejournal.com/64119.html (проверено 11.12 2018). 
мафиозным группировкам, криминальным структурам $-3,30 \%$, политическим партиям, общественным движениям $-2,20 \%{ }^{1}$.

Если говорить о сравнительном анализе двух социологических исследований, которые были проведены нами 2013 г. и 2015 г. (с приходом к власти Р. Абдулатипова и в предыдущий период), то можно сделать вывод, что ситуация в республике стабилизировалась. Однако говорить о полном размывании клановости, тем не менее, не приходится. Если на проведенном нами первом социологическом исследовании «Ожидания дагестанцев» на вопрос: «Кому принадлежит власть в республике?» - народ выбирал вариант ответа «клановой структуре», то теперь они выбирают ответ «главе региона».

Исследование 2017 г. (конец правления Р.Г. Абдулатипова) еще раз доказывает постепенное размывание клановости в республике. Так, на вопрос исследования: «Кому, на Ваш взгляд, реально принадлежит нынешняя власть в республике?» - были получены следующие ответы: «главе республики» - 13,6\%; «коррумпированной части аппарата» - 7,3\%; «мафиозным группировкам, криминальным структурам» - 5,1\%; «различным кланам» $-4,2 \%$; «политическим партиям, общественным движениям» - $1, \%$; «другое» - $1 \% 2$. Таким образом, можно отметить, что значимость принципа клановости в процентном соотношении с 2015 г. по 2017 г. снизилась с 15,8\% до 4,2\%.

Данное исследование выявило роль лидерской и персоналистской составляющих в эволюции элитного слоя, в котором респонденты выделили руководителя республики Р.Г. Абдулатипова. Тем не менее основными критериями вхождения в политическую элиту в Республике Дагестан остаются богатство, связи, стремление властвовать, клановость.

На вопрос исследования, проведенного автором: «Что, по Вашему мнению, прежде всего движет руководителями республики в их деятельности?» - были получены следующие ответы: «власть» - 20,3\%, «стремление стать богатым» $19,7 \%$, «привилегии и почести» - 15,2\%, «карьера»-12,9\%, «желание честно служить народу» - 2,8\% [Алигаджиева 2016].

По результатам аналогичного исследования 2017 г. на вопрос: «По представлению жителей Дагестана, что прежде всего движет руководителями республики в их деятельности»? - были получены следующие ответы: «стремление стать богатым» - 21\%; «желание получить власть» - 11,6\%; «добиться привилегий и почестей» - 3,3\%; «желание сделать карьеру» - 4,6\%; «желание честно служить народу» $-0,8 \%$; «другое» $-0,8 \% 3$. Результаты опросов подтверждают, что основной и главной целью власть имущих является стремление обогатиться за счет государства, преследуя личные интересы.

Отсюда можно прийти к выводу, что внутренняя сплоченность группы политической элиты, которая преследует собственные интересы, представляет собой очень сложный баланс. При этом выгоды в данной группе должны быть настолько большими, чтобы исключать переход человека в другую, еще более выгодную группу.

1 Материалы социологического исследования «Современная политическая элита в Республике Дагестан», организованного и проведенного автором в марте-августе 2015 г. в рамках работы Центра исследования глобальных вопросов современности и региональных проблем «Кавказ. Мир. Развитие». Метод - экспертный опрос. $\mathrm{N}=287$ чел. (эксперты, представители политической элиты, государственные служащие и общественные деятели).

2 Материалы социологического исследования «Современная политическая элита в Республике Дагестан», организованного и проведенного автором в сентябре-декабре 2017 г. в рамках работы Центра исследования глобальных вопросов современности и региональных проблем «Кавказ. Мир. Развитие». Метод - экспертный опрос. $\mathrm{N}=448$ чел. (эксперты, представители политической элиты, государственные служащие и общественные деятели).

3 Там же. 
Наиболее распространенным видом коррупции в республике является эндогенная коррупция ${ }^{1}$, в которой участвуют бюджетные организации и должностные лица, т.е. отношения происходят внутри властной структуры (или нескольких властных структур) между отдельными должностными лицами. Это тщательно разработанная система отмывания бюджетных денег, которая за последние два десятка лет приобрела невероятные масштабы ${ }^{2}$. На фоне в целом низкого уровня жизни коррумпированные группы накапливают огромные состояния.

Социальное дистанцирование между населением и политической элитой катастрофически возрастает. На вопрос: «Что, по Вашему мнению, прежде всего движет руководителями республики в их деятельности?» - были получены следующие ответы: «желание получить власть» - 20,3\%; «стремление стать богатым» - 19,7\%; «добиться привилегий и почестей» - 15,2\%; «желание сделать карьеру» - 12,9\%, «желание честно служить народу» - 2,8\% [Алигаджиева 2017: $117]$.

В соответствии с результатами опросов можно сделать вывод, что основные устремления политической элиты Дагестана сводятся к получению богатства.

Таким образом, не менее важной проблемой для региона в высших эшелонах власти является коррупция, которая мешает эффективному формированию политической элиты.

Контакты, связанные с бюджетными отношениями между центром и республикой, по мнению Г.А. Муркилинской, основываются на «откатах» теневой экономики, которые выгодны для узкой прослойки в правящих элитах как в центре, так и в республике [Добаев и др. 2010].

Систему «откатов», которая процветала в 1990-х гг. и продолжает существовать и ныне, стала нормой, и ее можно обнаружить практически во всех сферах деятельности республиканского руководства.

На вопрос: «Если Вы считаете, что эффективность республиканских руководителей недостаточно высока, то укажите причины этого», были получены следующие ответы: «коррумпированность чиновников» - 26,5\%; «некомпетентность руководителей» - 18,6\%; «оторванность властей от народа» - 15,2\%; «невыполнение законов» - 11,8\%» «низкая исполнительная дисциплина» $11,8 \%$; «низкая заработная плата» $-1,1 \%{ }^{3}$.

Именно коррумпированность чиновников, некомпетентность руководителей, клановость являются главными факторами, препятствующими качественному элитогенезу в Дагестане, от которого зависят эффективность деятельности политической элиты, ее качественный состав, профессиональная компетенция, лидерские позиции.

Кадровые перестановки и громкие аресты, прошедшие в республике с приходом Р.Г. Абдулатипова, дали положительную динамику - коррупционный бизнес пошатнулся. И несмотря на то что Р.Г. Абдулатипов в меньшей степени причастен к кланам в республике, тем не менее его семейно-родственные отношения и связи дают возможность многим старым кадрам оставаться на своей должности или перемещаться на аналогичные, и, следовательно, говорить о масштабном обновлении политической элиты не приходится.

Главными механизмами формирования региональной элитной структуры является взаимодействие с федеральными, политическими, экономическими, религиозными, этнократическими, интеллектуальными, антиэлитными груп-

\footnotetext{
${ }^{1}$ http://ignorik.ru/docs/index-2152463.html (проверено 11.05.2018).

2 http://bredikhinav.livejournal.com/64119.html (проверено 17.07.2015).

3 Материалы исследования «Современная политическая элита в Республике Дагестан», организованного и проведенного автором в марте-августе 2015 г.
} 
пами, для которых характерны родственные отношения и связи, богатство, деньги, личная преданность начальству, национализм, политико-экономические интересы. Основой всего служит проблема борьбы элиты за самосохранение. И при отсутствии действенных каналов обновления политической элиты можно наблюдать замкнутость элиты на самой себе. Поэтому дагестанский народ уже много раз выступал за назначение на пост главы республики человека из центра, который не зависел бы от кланов и родственных отношений. Может быть, поэтому дагестанский народ позитивно принял назначение на пост нового руководителя республики Владимира Васильева - первого русского на этом посту. Основным и главным вызовом для В. Васильева стало взаимодействие с местными кланами и борьба за их размывание. Начался период масштабной антикоррупционной кампании в республике.

Появление в республике человека, который практически не был погружен в местные реалии, по меньшей мере, меняет вводные условия задачи. Это позволяет рассчитывать на то, что к решению вечной проблемы Дагестана подойдут с принципиально новой стороны ${ }^{1}$.

Кремль стремится оправдать ожидания дагестанцев назначением на пост главы республики Васильева, который делает акцент на профессионализм и деловые качества. Особое внимание вновь назначенный президент уделяет борьбе с коррупцией, «которая приобретает системный характер», защите социальных и трудовых прав граждан, соблюдению законности в сфере ЖКХ и ТЭК, борьбе с нарушениями в сфере земельного законодательства и строительства, строгой регистрации всех преступлений и приоритету рассмотрения обращений граждан ${ }^{2}$. Кадровые зачистки В. Васильева дают молодежи и профессионалам шанс работать в интересах государства и ее граждан.

До прихода к власти В. Васильева каждый новый назначенец начинал свою деятельность с включения в команду родственников и близких ему людей. На вопрос исследования: «Какие факторы, по Вашему мнению, влияют на продвижение работников по службе в органах власти?» - самыми популярными ответами были названы: «семейно-родственные связи» $-23,1 \%$; «богатство, деньги» - 16,9\%; «профессионализм, квалификация» $-12,4 \%$; «поддержка богатых людей» - 10,1\%; «национальность» -9,6\%; «личная преданность начальству» 9\% [Алигаджиева 2016].

Результаты исследования показали, что вопрос обновления элиты был ограничен и практически заморожен на всех уровнях, т.к. циркуляция элит всегда происходила по линии кровных, родственных или определенных национальных идентичностей. Именно по такой системе всегда происходило формирование руководства, политической элиты, распределение должностей в регионе. Лояльность руководству представителей других этнических групп, входящих в элиту, создают видимость этнополитической мозаики политической системы. Однако они быстро превращаются в активных проводников этнократической политики своего патрона. Все это и многое другое приводит к этнизации ключевых сфер жизнеобеспечения, доходных мест, престижного образования и т.д. [Гриценко 2013].

С приходом В. Васильева в Дагестане начался этап размывания основ этнической и клановой структуры, идет процесс обновления политической элиты. Это переломный период в истории Дагестана, когда любой профессионал может участвовать в социально-политической жизни республики, власть максимально открыта для народа и готова отвечать ее запросам.

\footnotetext{
${ }^{1}$ Бодио Т. Указ. соч.

2 https://www.kommersant.ru/doc/3546578 (проверено 11.05.2018).
} 
Особое внимание уделяется качественному элитогенезу в Дагестане, от чего и зависят эффективность политической элиты, качественный состав элит, профессиональная компетентность, здоровые лидерские позициии.

\section{Список литературы}

Алигаджиева М.А. 2014. Элитогенез в политическом поле Дагестана. Известия Российского государственного университета им. А.И. Герцена. № 164. C. $167-172$.

Алигаджиева М.А. 2016. Критерии обновления политической элиты в Республике Дагестан. - Власть. № 2. С. 68-71.

Алигаджиева М.А. 2017. Современная политическая элита в республике Дагестан: состояние и тенденции развития. Махачкала: Изд-во ДГПУ. $153 \mathrm{c.}$

Гриценко Н.П. 2013. Особенности элитогенеза в политическом пространстве регионов современной России. - Мир и политика. Доступ: http://mirpolitika.ru/3001-osobennosti-elitogeneza-v-politicheskom-prostranstve-regionovsovremennoy-rossii.html

Добаев И.П., Мурклинская Г.А., СуховА.В., Ханбабаев К.М. 2010. Радикализация исламских движений в Центральной Азии и на Северном Кавказе: сравнительнополитологический анализ (под общ. ред. И.П. Добаева). Ростов н/Д: Изд-во СКНЦ ВШ ЮФУ. 230 с.

ALIGADJIEVA Madina Alievna, applicant of the Russian Presidential Academy of National Economy and Public Administration (RANEPA) (bld. 1,82 Vernadskogo Ave, Moscow, 119571, Russia; aligad_m@mail.ru)

\section{CLAN AND ETHNIC BLURRING OF THE POLITICAL ELITE OF DAGESTAN}

Abstract. Considering the internal and external challenges facing modern Russia, the role of the national-oriented elite is certainly increasing. The main trends for it should be the creation, preservation and stability of the country. The purpose of the article is to reveal the clan erosion of the political elite of the Republic of Dagestan. The work is prepared on the materials of sociological research conducted by the author by the method of questioning. The results obtained should be applied in the framework of the state policy of the Russian Federation in the field of national policy and interfaith relations for more complete awareness of state and municipal authorities, public organizations and movements.

Keywords: political elite, clans, blur, research, Dagestan 